\title{
Antimycobacterial activity evaluation and MIC determination of liophilizated hydroalcoholic extracts of Bixa orellana L., Bixaceae
}

\author{
Renata B. Silva, ${ }^{1}$ Cristina R. Almeida, ${ }^{1}$ Juliana M. Chavasco, ${ }^{2}$ Jorge K. Chavasco ${ }^{*}, 1$ \\ ${ }^{1}$ Universidade Federal de Alfenas, Rua Gabriel Monteiro da Silva, 714, 37130-000 Alfenas-MG, Brasil \\ ${ }^{2}$ Universidade José do Rosário Vellano, Unifenas, Rodovia MG 179, km 0, 37130-000 Alfenas-MG, Brasil.
}

\begin{abstract}
RESUMO: "Avaliação da atividade antimicobacteriana e a determinação da CIM de extratos hidroalcoólicos liofilizados de Bixa orellana L., Bixaceae." Bixa orellana é usada na medicina popular em várias doenças. Extratos do fruto, raiz e folhas apresentaram atividade antimicrobiana, enquanto extratos do caule mostraram resultados negativos. Este estudo teve por objetivo verificar a atividade antimicobacteriana de extratos hidroalcoólicos liofilizados de $B$. orellana frente Mycobacterium tuberculosis e determinar a Concentração Inibitória Mínima para cinco bactérias. A atividade antimicobacteriana foi determinada por difusão e a CIM por difusão e análise colorimétrica. As CIM foram $0,3,0,5$ e $0,2 \mathrm{mg} / \mathrm{mL}$ para os extratos de folhas, raiz e caule frente $M$. tuberculosis. Os extratos de caule demonstraram CIM de $1,12 \mathrm{mg} / \mathrm{mL}$ (B. cereus), 1,53 $\mathrm{mg} / \mathrm{mL}$ (S. aureus e $S$. typhimurium), 4,50 $\mathrm{mg} / \mathrm{mL}$ (P. aeruginosa) e $8,01 \mathrm{mg} / \mathrm{mL}$ (P. mirabillis); extratos de folhas mostraram $0,66 \mathrm{mg} / \mathrm{mL}$ (P. aeruginosa), $0,94 \mathrm{mg} / \mathrm{mL}$ (P. mirabillis), $1,88 \mathrm{mg} / \mathrm{mL}$ (S. aureus), 3,95 mg/mL (B. cereus) e $8,37 \mathrm{mg} / \mathrm{mL}$ (S. typhimurium); extratos de raiz demonstraram $0,25 \mathrm{mg} / \mathrm{mL}$ (P. aeruginosa), 0,31 mg/mL (S. aureus), $0,62 \mathrm{mg} / \mathrm{mL}$ (S. typhimurium) e 3,00 mg/ $\mathrm{mL}$ (B. cereus e $P$. mirabillis). Extratos de folhas e caule mostraram atividade antimicobacteriana. As CIM por colorimetria foram menores que na difusão em agar. Os extratos revelaram atividade bacteriostática sobre as cinco espécies bacterianas.
\end{abstract}

Unitermos: Mycobacterium tuberculosis, Bixa orellana, Bixaceae.

\begin{abstract}
Bixa orellana is used in popular medicine against several diseases. Extracts of its fruit, root and leaf presented antimicrobial activity, while seed extract showed negative results. This study aimed at verifying the antimycobacterial activity of $B$. orellana lyophilized hydroalcoholic extracts over Mycobacterium tuberculosis, and determine the Minimum Inhibitory Concentration against five bacteria. Antimycobacterial activity was determined by diffusion technique, while MIC was assessed by diffusion and colorimetric analysis. MICs were $0.3,0.5$ and $0.2 \mathrm{mg} / \mathrm{mL}$ respectively, for leaf, root and stem extracts, against $M$. tuberculosis. Stem's extract showed 1.2 $\mathrm{mg} / \mathrm{mL}$ for B. cereus, $1.53 \mathrm{mg} / \mathrm{mL}$ for $S$. aureus and $S$. typhimurium, $4.50 \mathrm{mg} / \mathrm{mL}$ for $P$. aeruginosa and $8.01 \mathrm{mg} / \mathrm{mL}$ for $P$. mirabillis. Leaf extracts showed $0.66 \mathrm{mg} / \mathrm{mL}$ for $P$. aeruginosa, $0.94 \mathrm{mg} /$ $\mathrm{mL}$ for P. mirabillis, $1.88 \mathrm{mg} / \mathrm{mL}$ for $S$. aureus, $3.95 \mathrm{mg} / \mathrm{mL}$ for $B$. cereus and $8.37 \mathrm{mg} / \mathrm{mL}$ for $S$. typhimurium. Root's extracts showed $0.25 \mathrm{mg} / \mathrm{mL}$ for $P$. aeruginosa, $0.31 \mathrm{mg} / \mathrm{mL}$ for $S$. aureus, $0.62 \mathrm{mg} / \mathrm{mL}$ for $S$. typhimurium and $3.00 \mathrm{mg} / \mathrm{mL}$ for B. cereus and P. mirabillis. Leaf and stem extracts showed antimycobacterial activity. MICs were lower in colorimetric analysis than in agar diffusion. Extracts revealed bacteriostatic activity against the five bacterial.
\end{abstract}

Keywords: Mycobacterium tuberculosis, Bixa orellana, Bixaceae.

\section{INTRODUCTION}

Brazilian flora is very rich and composed by approximately twenty thousand different species being Bixa orellana $\mathrm{L}$. is one of them, which is part of the family of the Bixaceae and commonly known as annatto. It is a small tree growing 3 to $5 \mathrm{~m}$ in height, with a developed treetop. The leaf is simple, beardless, measuring 8 to $15 \mathrm{~cm}$ in length. It is a species from Tropical America including the Brazilian Amazon (Lorenzi \& Matos, 2002). Besides being a food additive, annatto is used in the popular medicine against coronary illnesses, stomach and intestine affections, burns, respiratory affections and also as aphrodisiac. The leaves are used to combat fever and kidney affections (Lorenzi \& Matos, 2002).

Brazil is one of the major world annatto grain producers. From this production $70 \%$ are used in cooking, $20 \%$ as natural dye or as food coloring, and $10 \%$ to 
exportation. Agner et al. (2005) studied effect of annatto on preneoplasic lesions induced by DMH and on DNA damage on rat's colons. Under experimental conditions, annato did not develop any adverse effect and results suggested possible chemopreventive effects by its cellular proliferation modulation, but not in the carcinogenesis initial stage (Agner et al., 2005). In studies with rabbits, bixin and norbixin, carothenoids found in annatto, yielded promising results for a possible future use to either prevent or treat cardiac illness (Lima et al., 2001). Intraperitoneal doses of $500 \mathrm{mg} / \mathrm{kg}$ to $1000 \mathrm{mg} / \mathrm{kg}$ in rats caused an increase of diuresis and reduction on muscular activity, without toxicity apparent signal. In this situation LD was of $700 \mathrm{mg} / \mathrm{kg}$. Since $1970 \mathrm{FAO} / \mathrm{WHO}$ permit a temporary daily ingestion of $1.25 \mathrm{mg} / \mathrm{kg}$ body weight of annatto extracts.

Antimicrobial activity has been demonstrated $B$. orellana in extracts of fruits, root and leaf but not in seed extracts (Caceres et al., 1990; Caceres et al., 1995). Huhtanen (1980) studied annatto fruit dyeing with Clostridium botulinum and determined the MIC value in 31 ppm. Pinto Coelho (2003) reported antimicrobial activity of annatto against several microbial species using hydroalcoholic extracts of stem, flower, fruit, and root only dry fruit extract did not present antimicrobial activity (Pinto Coelho et al., 2003). The importance of studies to verify the antimicrobial activity of plants is increasing due to the increasing resistance of microorganisms to the antibiotics currently commercialized. As reported in the literature, Mycobacterium tuberculosis is also becoming resistant to the antibiotics proposed by World Health Organization to combat tuberculosis, probably because of the long time of treatment and the adverse effects of these drugs, factors that hinder the patients adapt to therapy (Trabulsi, 2005).

With the purpose of amplifying the knowledge of medical plants with antimicrobial potential, this study evaluated the antimicobacterial activity of Bixa orellana and determined the Minimum Inhibitory Concentration (MIC) of lyophilized hydroalcoholic extracts of $B$. orellana L. leaf, root and stem against Salmonella typhimurium (ATCC 14028), Proteus mirabilis (ATCC 25933), Bacilus cereus (ATCC 11778), Staphyloccocus aureus (ATCC 12228) and Pseudomonas aeruginosa (ATCC 27853).

\section{MATERIALS AND METHODS}

Samples of root, stem and leaf of Bixa orellana L. were collected in Sitio da Lagoa, in Alfenas-MG, in October 2005 and sent Universidade Federal de Lavras, where they were botanically indentified and deposited in the herbarium under number 15.817 .

According to the technique described by Cáceres et al. (1990, 1995), material was placed on domestic blender with ethanol $70{ }^{\circ} \mathrm{GL}$ to be triturated (in the ratio of 800 $\mathrm{mL}$ of ethanol to $200 \mathrm{~g}$ of sample). Then, the mixture was allowed to macerate, protected against light and ambient temperature during seven days. Extracts were filtered and concentrated with rotatory concentrator. Aliquots of each extract were used for microbiological trial and showed inhibition halos with all tested bacteria. Extracts were lyophilized and their masses were quantified.

With the adapted agar diffusion technique described by Bauer et al. (1966), the MIC of root, stem and leaf extracts were tested against Salmonella typhimurium, Proteus mirabilis, Bacilus cereus, Staphyloccocus aureus e Pseudomonas aeruginosa and then submitted to colorimetric. In these tests different dilutions of root, stem and leaf extracts of $B$. orellana, prepared with bases on the MIC found to each microorganism were incorporated into Muller Hinton broth with $2 \%$ of Isopropil miristate and $100 \mu \mathrm{L}$ of bacterial suspension, with a tube turbidity of approximately 0.5 on the McFarland Scale. Positive and negative controls were used for the tests. The tubes were incubated at $37^{\circ} \mathrm{C}$ during $18 \mathrm{~h}$. At this stage, results were obtained by colorimetric reading of the tubes, after shaking them with a vortex. Each tube was read before and after incubation and the difference between the first and second readings values was obtained. Bacteriostatic or bactericidal activity was evaluated in each tube.

According to Dutta et al. (2004) antimycobacterial activity was determined by diffusion technique in Lowenstein Jensen medium (LJM). Distilled water (1.5 $\mathrm{mL}$ ) was added to lyophilized extracts and filtered with a $0.22 \mu \mathrm{m}$ membrane. After this, $7 \mu \mathrm{L}$ of each extract were added to filter paper discs. Positive controls of LJM and negative controls with $7 \mathrm{uL}$ of Rifamicine ${ }^{\circledR}(30 \mu \mathrm{g} / \mathrm{mL})$ were used. Inoculation in LJM with strain ATCC 25177 (H37Ra) was done with turbidity approximated to 0.5 on the McFarland Scale tube. Than MICs were determined by adding decreasing extracts concentrations of 30.0 to $0.05 \mathrm{mg} / \mathrm{mL}$ in Lowenstein Jensen medium and observing in witch of the tubes the microorganism did not showed growth after twenty eight days at $37{ }^{\circ} \mathrm{C}$. Positive control was done using inoculated LJM, negative control of LJM and Rifamicine ${ }^{\circledR}(30 \mu \mathrm{g} / \mathrm{mL})$ and sterility control with LJM only. These experiments run on triplicate.

\section{RESULTS}

Stem's extract showed MIC of $1.12 \mathrm{mg} / \mathrm{mL}$ for B. cereus, $1.53 \mathrm{mg} / \mathrm{mL}$ for $S$. aureus and $S$. typhimurium, $4.50 \mathrm{mg} / \mathrm{mL}$ for $P$. aeruginosa and $8.01 \mathrm{mg} / \mathrm{mL}$ for $P$. mirabillis; lead's extract showed MIC of $0.66 \mathrm{mg} / \mathrm{mL}$ for P. aeruginosa, $0.94 \mathrm{mg} / \mathrm{mL}$ for $P$. mirabillis, $1.88 \mathrm{mg} / \mathrm{mL}$ for $S$. aureus, $3.95 \mathrm{mg} / \mathrm{mL}$ for B. cereus and $8.37 \mathrm{mg} / \mathrm{mL}$ for $S$. typhimurium; root's extract showed MICs of 0.25 $\mathrm{mg} / \mathrm{mL}$ for $P$. aeruginosa, $0.31 \mathrm{mg} / \mathrm{mL}$ for $S$. aureus, 0.62 $\mathrm{mg} / \mathrm{mL}$ for $S$. typhimurium and $3.00 \mathrm{mg} / \mathrm{mL}$ for $B$. cereus and $P$. mirabillis (Table 1). MICs were $0.3 \mathrm{mg} / \mathrm{mL}, 0.5$ $\mathrm{mg} / \mathrm{mL}$ and $0.2 \mathrm{mg} / \mathrm{mL}$ for leafs, root and stem extracts, respectively against $M$. tuberculosis (Table 2). 
Table 1. Results of tests to determine MIC of extracts of Bixa orellana.

Minimum Inhibitory Concentration $(\mathrm{mg} / \mathrm{mL})$

Microrganism

Agar difusion tests

colorimetric tests

\begin{tabular}{lcccccc} 
& Stem extract & Root extract & Leafs extract & Stem extract & Root extract & Leafs extract \\
\hline Staphylococcus aureus & 34.71 & 14.09 & 18.88 & 1.53 & 0.31 & 1.88 \\
Salmonella typhimurium & 34.71 & 14.09 & 75.54 & 1.53 & 0.62 & 8.37 \\
Proteus mirabilis & 105.93 & 28.18 & 18.88 & 8.01 & 3.00 & 0.94 \\
Pseudomonas aeruginosa & 17.77 & 75.06 & 75.54 & 4.50 & 0.25 & 0.66 \\
Bacillus cereus & 34.71 & 28.18 & 14.17 & 1.12 & 3.00 & 3.95 \\
\hline
\end{tabular}

Table 2. Determination of antimycobacterial activity of leaf, root, and stem extracts of Bixa orellana against Mycobacterium tuberculosis.

\begin{tabular}{|c|c|c|c|}
\hline Tested Discs & $\begin{array}{l}\text { Diameter of inhibition halos } \\
\qquad(\mathrm{mm})\end{array}$ & Tested tubes & $\begin{array}{l}\text { MIC of Bixa orellana against } \\
\text { Mycobacterium tuberculosis } \\
(\mathrm{mg} / \mathrm{mL})\end{array}$ \\
\hline Leaf Extract & 30.0 & Leaf extract & 0.3 \\
\hline Root Extract & 11.0 & Root extract & 0.5 \\
\hline Stem Extract & 16.0 & Stem extract & 0.2 \\
\hline $\operatorname{Rifamicine~}^{\circledR}(30 \mu \mathrm{g} / \mathrm{mL})$ & 26.0 & - & - \\
\hline Water & - & - & - \\
\hline
\end{tabular}

\section{DISCUSSION}

Fleischer et al. (2003) evaluated the antimicrobial activity of $B$. orellana lyophilized hydroalcoholic extracts with $10 \mathrm{mg} / \mathrm{mL}$ against Candida albicans and Grampositive and Gram-negative bacteria, three of them being Staphylococcus aureus, Salmonella typhimurium and Pseudomonas aeruginosa. Our extracts showed antimicrobial activity against five microorganisms. Leafs extract shwoed higher inhibition against $S$. typhimurium and $P$. aeruginosa when compared whit stem and root extract. For $P$. aeruginosam halos were similar for roots and leaf extracts.

Rojas (2006) evaluated antimicrobial activity of ten plants extracts and determinate the MIC against five bacteria, three of them being Staphylococcus aureus (ATCC 29737), Bacillus cereus (ATCC 14603) and Pseudomonas aeruginosa (ATCC 25619), and against Candida albicans (ATCC 53324). Bixa orellana showed the best MIC for B. cereus $(0.2 \mu \mathrm{g} / \mathrm{mL})$ comparing to gentamicine control $(0.5$ $\mu \mathrm{g} / \mathrm{mL})$. However, none of the extracts showed activity against Streptococcus $\beta$-hemoliticus (ATCC 10389) and $P$. aeruginosa. In our experiments $B$. cereus sowed the smaller inhibition halos whith leaf extracts when compared with root and stem extracts using agar diffusion tests, and $P$. aeruginosa demonstrated the lowest MIC whith root extracts using colorimetric tests (Table 1).

MICs determined by agar diffusion were higher than the ones obtained by colorimetric methods because extracts can have more contact with microorganisms when suspension is used and colorimetric tests allows more sensitive results. Using the agar diffusion technique,
MIC varied from $14.17 \mathrm{mg} / \mathrm{mL}$ to $75.54 \mathrm{mg} / \mathrm{mL}$ for leaf extracts. The present results demonstrated lower MIC for Bacillus cereus with leaf extract, for Staphylococcus aureus and Salmonella typhimurium with root extract and for Pseudomonas aeruginosa with stem extract. Using colorimetric technique, MIC varied from $0.66 \mathrm{mg} / \mathrm{mL}$ to $8.37 \mathrm{mg} / \mathrm{mL}$ for leaf extracts. Our results demonstrated lower MIC for Pseudomonas aeruginosa with leaf extract, for Pseudomonas aeruginosa with root extract and for Bacillus cereus with stem extract (Table 1).

As reported in the literature, variations can occur due to concentrations differences of antimicrobial substances on the botanical material and respective extracts, in environmental factors where plants are located, in the period when the material was collected or even because of genetic differences in plant species. In addition variations can also occur due to the use of different microorganism strains.

Inhibition halos with stem and leaf extracts against Mycobacterium tuberculosis confirm popular medicine reports of Bixa orellana utilization against tuberculosis (Table 2). In the diffusion test the leaf extract showed an inhibition halo of $30 \mathrm{~mm}$, larger than the Rifamicine control. It was also generally show that the MICS of roots, leaf and stem extracts were smaller for M. tuberculosis when compared to those of other bacteria. Thus, B. orellana extract could have this activity due to phenolic or saponin components. Alkaloids are known to act on extra-cellular proteins and maybe this fact can explain antimicrobial activity. 


\section{CONCLUSIONS}

The results obtained in these studies showed lower MIC of extracts evaluated by colorimetric technique when compared to agar diffusion technique used as trial tests. Stem, root and leaf hydroalcoholic extracts of Bixa orellana L. showed bacteriostatic activity against Salmonella typhimurium (ATCC 14028), Proteus mirabilis (ATCC 25933), Bacilus cereus (ATCC 11778), Staphyloccocus aureus (ATCC 12228) and Pseudomonas aeruginosa (ATCC 27853) antimycobacterial activity was determined in leaf, root and stem hydroalcoholic extracts of Bixa orellana L. against Mycobacterium tuberculosis ATCC 25177 (H37Ra).

\section{ACKNOWLEDGMENTS}

The authors thank UFLA for botanical material identification, $\mathrm{CNPq}$ for financial support, UNIFALMG for collaboration and IAL-SP for Mycobacterium tuberculosis strains and Professor Vinicius Vieira Vignoli (UNIFENAS) for language review.

\section{REFERENCES}

Agner A, Bazo AP, Ribeiro LR, Salvadori DMF 2005. DNA damage and aberrant crypt foci as putative biomarkers to evaluate the chemopreventive effect of annatto (Bixa orellana L.) in rat colon carcinogenesis. Mutat. Res. 582: 146-154.

Bauer AW, Kirby WM, Sherris JC, Turck M 1966. Antibiotic susceptibiliy testing by a standardized single disc method. Am J Clin Pathol 45: 493-496.

Caceres A, Cano O, Samayoa B, Aguilar L 1990. Plants used in Guatemala for the treatment of gastrointestinal disorders. Screening of 84 plants against enterobacteria. J Ethnopharmacol 30: 55-73.

Cáceres A, Menéndez H, Méndez E, Cohobón E, Samayoa BE, Jauregui E, Peralta E, Carrillo G. 1995. Antigonorrhoeal activity of plants used in Guatemala for the treatment of sexually transmitted diseases. J Ethnopharmacol 48: 8588.

Dutta NK, Dastidar SG, Kumar A, Mazumdar K, Ray R, Chakrabarty AN 2004. Antimycobacterial activity of the antiinflammatory agent diclofenac sodium, and its synergism with streptomycin. Braz J Microbiol 35: 316323.

Fleischer TC, Ameade EPK, Mensah MLK, Sawer IK 2003. Antimicrobial activity of the leaves and seeds of Bixa orellana. Fitoterapia 74: 136-138.

Huhtanen CN 1980. Inhibition of Clostridium botulinum by spice extracts and aliphatic alcohols. J Food Protec 43: 195196.

Lima LRP, Oliveira TT, Nagem TJ, Pinto AS, Stringheta PC, Tinoco ALA, Silva JF 2001. Bixina, norbixina e quercetina e seus efeitos no metabolismo lipídico de coelhos. Braz J Vet Res Anim Sci 38: 196-200.

Lorenzi H, Matos FJA 2002. Plantas medicinais no Brasil: nativas e exóticas. Instituto Plantarum: Nova Odessa.

Pinto Coelho,AMS, Silva GA, Vieira MC, Chavasco JK 2003. Atividade antimicrobiana de Bixa orellana L. (Urucum), Rev Lecta 1/2: 47-54.Rodrigues LA, Fracasso JF, Yashuda Y 1998. The hipotensive action of the extracts from seeds of Bixa orellana L. Rev Cienc Farm 10: 41-44.

Rojas JJ, Ochoat VJ, Ocampo SA, Muñoz JF 2006. Screening for antimicrobial activity of ten medicinal plants used in Colombian folkloric medicine: A possible alternative in the treatment of non-nosocomial infections. BMC Compl Alt Med 6: 2-7.

Trabulsi LR, Althertum F 2005. Microbiologia, $4^{\circ}$ ed. São Paulo: Editora Atheneu. 